\title{
Involvement of the Genetic Diversity of HIV-1 in the Virological Treatment Failure of First Line Antiretroviral in Kinshasa
}

\section{Erick Ntambwe Kamangu1 ${ }^{*}$, Richard Lunganza Kalala1, Georges Lelo Mvumbi1, Dolores Vaira ${ }^{2}$, Marie-Pierre Hayette ${ }^{2,3}$}

\author{
${ }^{1}$ Molecular Biology Unit, Department of Basic Sciences, Faculty of Medicine, University of Kinshasa (UNIKIN), Kinshasa, \\ Democratic Republic of Congo (DRC) \\ ${ }^{2}$ AIDS Reference Laboratory (ARL), Centre Hospitalier Universitaire-Université de Liège (CHU-Lg), Liège, Belgium \\ ${ }^{3}$ Clinical Microbiology Laboratory, Centre Hospitalier Universitaire-Université de Liège (CHU-Lg), Liège, Belgium \\ Email: *erick.kamangu@unikin.ac.cd, ^erickamangu@gmail.com
}

How to cite this paper: Ntambwe Kamangu, E., Lunganza Kalala, R., Lelo Mvumbi, G., Vaira, D. and Hayette, M.-P. (2017) Involvement of the Genetic Diversity of HIV-1 in the Virological Treatment Failure of First Line Antiretroviral in Kinshasa. World Journal of AIDS, 7, 23-33. https://doi.org/10.4236/wja.2017.71003

Received: May 4, 2015

Accepted: May 11, 2015

Published: February 24, 2017

Copyright $\odot 2017$ by authors and Scientific Research Publishing Inc. This work is licensed under the Creative Commons Attribution International License (CC BY 4.0).

http://creativecommons.org/licenses/by/4.0/

\begin{abstract}
Background: Genetic diversity of human immunodeficiency virus affects the treatment and the emergence of resistance. Some subtypes would develop resistance more frequently than others. The aim of this study is to determine the rate of virological treatment failure and the involvement of genetic diversity and different mutations in this failure in Kinshasa. Methods: Of the 153 Antiretroviral-naive patients who were included in the cohort, 138 patients have been received for the appointment of the $6^{\text {th }}$ month. Clinical parameters were recorded on individual patient charts. The determination of Viral Load (VL) was done at the Laboratory of Molecular Biology. Clinical and biological parameters of the $6^{\text {th }}$ month were compared with those taken at baseline of the cohort to determine the evolution of patients under treatment. Results: At the consultation of the $6^{\text {th }}$ month, 138 patients $(90.2 \%)$ had returned out of the 153 included. Eighty-one (58.7\%) patients were women and 57 (41.3\%) men. The age of patients is between 18 and 65 with an average of 37 years. Ten deaths $(6.5 \%)$ and $5(3.3 \%)$ lost have been reported. One hundred twenty-five patients (90.5\%) were in clinical stage 3 and 13 (9.5\%) in clinical stage 4 . The median CD4 T cells is 560 cells $\mathrm{mm}^{3}$. The median VLs of patients was 0.90 $\log _{10}$ RNA copies $/ \mathrm{ml}$. Of the 34 patients in virological failure, 8 (23.5\%) are minimal failure, $23(67.7 \%)$ in moderate failure and $3(8.8 \%)$ in severe failure. According to the Pearson's test, VLs at $6^{\text {th }}$ months were highly correlated with that of inclusion, with V75 and K70 mutations for NRTIs, with V108 mutation for NNRTI well as the virological failure of treatment. Conclusion: Our results confirmed the hypothesis that high Viral Load at the start of the treatment is a poor prognosis for the development of therapy. Transmitted muta-
\end{abstract}


tions are involved in treatment failure.

\section{Keywords}

HIV, Subtypes, Resistance, Treatment Failure, Kinshasa

\section{Backgrounds}

The Human Immunodeficiency Virus (HIV) has a genetic diversity that is equal to the complexity of its management [1]. The classification of types, groups, subgroups, sub-groups and different recombinant forms (CRFs-Circulating Recombinant Forms) or mutant allowed better understanding the virus, its geographical distribution and the evolution of the epidemic [1]-[7]. It also helped direct the management of patients infected by HIV [1]-[7]. Group M (Major) is the dominant group in Central Africa [1]-[7]. The distribution of this group in Africa and the Democratic Republic of Congo (DRC), in particular, is very heterogeneous; it follows a complex and specific algorithm [1]-[7]. This distribution is very dynamic, progressive and unpredictable; it will continue to diversify as long as the virus circulates [1]-[7]. There is a very large genetic diversity of this group $M$ in the DRC and particularly in Kinshasa [1]-[7]. The subtype B, which is the dominant one in Western Europe and North America has a prevalence $<1 \%$ in Kinshasa [1].

The genetic diversity of HIV affects the treatment and the emergence of resistant strains [8]. Some subtypes would develop resistance more frequently than subtypes A and B [9]; this could cause some natural nucleotide polymorphisms on specific codons [10] [11].

Treatment failure includes a variety of situations, whether virological failure resulting from a persistent viral replication 6 months after starting treatment (Viral load $>200$ RNA copies/ml or $2.30 \log _{10}$ RNA copies/ml), an immunological failure with persistent immunodeficiency $\left(\mathrm{CD} 4\right.$ count $\left.<200 \mathrm{cells} / \mathrm{mm}^{3}\right)$ or clinical failure that usually associated virological failure and immune deterioration [12]. In 2012, 16\% of patients in the first line antiretroviral therapy (ART) were estimated in treatment failure in Kinshasa [13].

The aim of this study is to determine the rate of virological treatment failure and the involvement of genetic diversity and different mutations in this failure in Kinshasa.

\section{Methodology}

\subsection{Study Population}

At baseline, 153 patients naïve to Antiretroviral Therapy (ART) were selected for follow-up with different support centers in Kinshasa. The inclusion criteria for subjects in the cohort were: (i) being diagnosed HIV-1 positive according to national guidelines [14], (ii) being over the age of 18 years at the inclusion in the 
cohort, (iii) being eligible for ART in the monitoring center and (iv) be naive to ART. Viral Loads (VL), the different HIV-1 strains and the different mutations associated with resistance to ART were determined for all patients at baseline [15] [16]. The $6^{\text {th }}$ month of ART, only 138 patients (90.2\%) of the cohort have been received on the 153 included in the first day.

\subsection{Clinical and Biological Monitoring Parameters}

Clinical parameters were collected on individual patient charts in their respective centers as well as the survey forms. The determination of the VL was done in the laboratory of Molecular Biology of the Faculty of Medicine University of Kinshasa (UNIKIN) using the same "in-house" assays used at the inclusion [16] [17] [18] [19]. The count of CD4+ lymphocytes was done by flow cytometry.

\subsection{Comparison of Variables}

In order to determine the evolution of patients under treatment, clinical and biological parameters of the $6^{\text {th }}$ month were compared with those taken at baseline of the cohort [15] [16] [17] [18]. For compliance, clinical parameters are evaluated according to the classification of the World Health Organization (WHO); VLs were determined using the same "in-house" assays under the same conditions. Correlation tests were done between profiles at baseline and those at the $6^{\text {th }}$ month, VLs at baseline and mortality, VLs at baseline and treatment failure, and the prevalence of acquired mutations and failures treatment.

\subsection{Statistics}

Pearson correlation test was used to analyze the data. The value of $p<0.06$ is considered to accommodate the size of our sample.

\subsection{Operational Definition}

The virological failure is defined as a persistent VL higher than 200 RNA copies/ml $\left(2.30 \log _{10}\right.$ RNA copies $\left./ \mathrm{ml}\right) 6$ months after the start of treatment [20]. Three definitions are presented for virological failure: the minimal failure $(200<$ $\mathrm{VL}<5000$ or $2.30 \log _{10}<\mathrm{VL}<3.70 \log _{10}$ RNA copies/ml), moderate failure $\left(5000<\mathrm{VL}<30000\right.$ or $3.70 \log _{10}<\mathrm{VL}<4.48 \log _{10} \mathrm{RNA}$ copies/ml) and severe failure (VL $>30000$ or VL $>4.48 \log _{10}$ RNA copies/ml) [20] [21]. The patients lost are those who did not return for their appointment the $6^{\text {th }}$ month and have not been found by the community relay service from the centers.

\section{Results}

\subsection{Epidemiological Data}

At the $6^{\text {th }}$ month follow-up, 138 patients (90.2\%) had returned out of the 153 patients included at baseline. Eighty-one (58.7\%) patients were women and 57 (41.3\%) male (Table 1); with a sex ratio M/F of $0.70(\mathrm{p}<0.06)$. The age of patients ranges between 18 and 65 years with an average of 37 years (Table 1). The 
Table 1. Characteristics of patients.

\begin{tabular}{|c|c|}
\hline Characteristics & Patients \\
\hline \multicolumn{2}{|c|}{$\operatorname{Sex}(n=138)$} \\
\hline Male & $57(41.3 \%)$ \\
\hline Female & $81(58.7 \%)$ \\
\hline \multicolumn{2}{|c|}{ Age $($ years $)(n=138)$} \\
\hline Range & $18-65$ years \\
\hline Mean & 37 years \\
\hline $18-25$ & $30(21.7 \%)$ \\
\hline $26-35$ & $39(28.3 \%)$ \\
\hline $36-45$ & $39(28.3 \%)$ \\
\hline $46-55$ & $23(16.7 \%)$ \\
\hline $56-65$ & $7(5.1 \%)$ \\
\hline \multicolumn{2}{|c|}{ Viral Load $\left(\log _{10}\right.$ copies of RNA/ml) $(\mathrm{n}=138)$} \\
\hline Range & $0-4,82 \log _{10}$ \\
\hline Median & $0,90 \log _{10}$ \\
\hline \multicolumn{2}{|c|}{ CD4 cells count $($ Cells $/ \mathrm{ml})(\mathrm{n}=113)$} \\
\hline Range & $98-1050$ \\
\hline Median & 480 \\
\hline
\end{tabular}

age intervals most represented are of 26 to 35 and 36 to 45 years with 39 patients (28.3\%) each, followed by that of 18 to 25 years (21.7\%), 46 to 55 years (16.7\%) and 56 to 65 years $(5.1 \%)$. Ten deaths $(6.5 \%)$ were reported and 5 patients (3.3\%) were lost to the services of community relays respective of the centers (Table 2).

At baseline, 153 patients naïve to Antiretroviral Therapy (ART) were selected for follow-up. Ninety-one (60.1\%) patients were women and $62(39.9 \%)$ men with a sex ratio $\mathrm{M} / \mathrm{F}$ of $0.68(\mathrm{p}<0.06)$. The age of patients is in the range 18 to 65 years with a mean of 37 years. The age group most represented at the beginning of the study was that of 26 to 35 years with 42 patients (27.45\%); followed by 36 to 45 years (26.14\%), 18 to 25 years (20.92\%), 46 to 55 years $(16.99 \%)$ and 56 to 65 years $(8.50 \%)[16]$.

\subsection{Clinical and Biological Data}

At $6^{\text {th }}$ months, 5 patients were lost from the relays service ( 2 women and 3 men) and 10 patients were reported dead ( 8 women and 2 men) (Table 2). One hundred twenty-five patients (90.5\%) were in clinical stage 3 and 13 (9.5\%) in clinical stage 4 according to the WHO classification. The rate of CD4 T cells, which were made for 113 patients (71\%) were between 98 and 1050 cells $/ \mathrm{mm}^{3}$ with 52 patients $(46.02 \%)$ having CD4 counts greater than 500 cells $/ \mathrm{mm}^{3}$ and a median value of 560 cells $/ \mathrm{mm}^{3}$ (Table 1). The median VLs of patients was $0.90 \log _{10}$ 
Table 2. Cases of death and patients lost.

\begin{tabular}{|c|c|c|c|}
\hline Parameters & \multicolumn{3}{|c|}{ Frequencies } \\
\hline \multicolumn{4}{|c|}{ Case of deaths $(n=10)$} \\
\hline Male & & $2(20.0 \%)$ & \\
\hline \multirow[t]{2}{*}{ Female } & & $8(80.0 \%)$ & \\
\hline & Male & Female & Total \\
\hline $18-25$ & 0 & 0 & 0 \\
\hline $26-35$ & $1(10.0 \%)$ & $1(10.0 \%)$ & $2(20.0 \%)$ \\
\hline $36-45$ & 0 & 0 & 0 \\
\hline $46-55$ & 0 & $3(30.0 \%)$ & $3(30.0 \%)$ \\
\hline $56-65$ & $1(10.0 \%)$ & $4(40.0 \%)$ & $5(50.0 \%)$ \\
\hline Total & $2(20.0 \%)$ & $8(80.0 \%)$ & $10(100.0 \%)$ \\
\hline \multicolumn{4}{|c|}{ Case of patients lost from Treatment Centers $(n=5)$} \\
\hline Male & & $3(60.0 \%)$ & \\
\hline \multirow[t]{2}{*}{ Female } & & $2(40.0 \%)$ & \\
\hline & Male & Female & Total \\
\hline $18-25$ & $1(20.0 \%)$ & $1(20.0 \%)$ & $2(40.0 \%)$ \\
\hline $26-35$ & $1(20.0 \%)$ & 0 & $1(20.0 \%)$ \\
\hline $36-45$ & 0 & $1(20.0 \%)$ & $1(20.0 \%)$ \\
\hline $46-55$ & 0 & 0 & 0 \\
\hline $56-65$ & $1(20.0 \%)$ & 0 & $1(20.0 \%)$ \\
\hline Total & $3(60.0 \%)$ & $2(40.0 \%)$ & $5(100.0 \%)$ \\
\hline
\end{tabular}

RNA copies $/ \mathrm{ml}$. The minimum and maximum values were respectively 0 and $4.82 \log _{10}$ RNA copies/ml with 104 patients (75.4\%) with a VLunder 200 RNA copies $/ \mathrm{ml}$ or $2.3 \log _{10}$ RNA copies/ml giving a rate of virological failure of $24.6 \%$ (Table 3). Of the 34 patients in virological failure, 8 (23.5\%) are minimal failure (2.30 $\log _{10}<\mathrm{VL}<3.70 \log _{10}$ RNA copies/ml), 23 (67.7\%) in moderate failure $\left(3.70 \log _{10}<\mathrm{VL}<4.48 \log _{10}\right.$ RNA copies/ml) and $3(8.8 \%)$ in severe failure (VL $>$ $4.48 \log _{10}$ RNA copies/ml) (Table 3 ).

At baseline, 140 patients (91.5\%) were in clinical stage 3 and 13 (8.5\%) in clinical stage 4 for HIV infection as classified by the World Health Organization (WHO) [16]. The rates of CD4 T cells were between 8 and 915 cells $/ \mathrm{mm}^{3}$ with 69 patients (86.8\%) with CD4 counts below 500 cells $/ \mathrm{mm}^{3}$ [15] [16]. The median Viral Loads (VL) of the included patients was $5.68 \log _{10}$ RNA copies/ml [15] [16] [17] [18]. The minimum and maximum values were respectively $0.37 \log _{10}$ and $7.95 \log _{10}$ RNA copies/ml with 97 patients $(63.4 \%)$ with a VL greater than 100,000 RNA copies/ml or $5.0 \log _{10}$ copies RNA copies/ml [15] [16] [17] [18]. Nearly $18 \%$ of patients had major mutations associated with Nucleoside Reverse Transcriptase Inhibitors (NRTI), almost $10 \%$ for major mutations associated with Non-Nucleoside Reverse Transcriptase Inhibitors (NNRTI) and 2\% for major mutations associated with Protease Inhibitors (PI) [15]. 
Table 3. Prevalence of virological failure.

\begin{tabular}{|c|c|c|}
\hline Characteristics & \multicolumn{2}{|c|}{ Frequencies } \\
\hline Therapeutic Success $C V<2,30 \log _{10}$ & \multicolumn{2}{|c|}{$104(75.4 \%)$} \\
\hline Therapeutic Failure $C V>2,30 \log _{10}$ & \multicolumn{2}{|c|}{$34(24.6 \%)$} \\
\hline \multicolumn{3}{|c|}{ Age Interval } \\
\hline & $<2,30 \log _{10}$ & $>2,30 \log _{10}$ \\
\hline $18-25$ & $18(17.3 \%)$ & $12(35.3 \%)$ \\
\hline $26-35$ & $31(29.8 \%)$ & $8(23.5 \%)$ \\
\hline $36-45$ & $31(29.8 \%)$ & $8(23.5 \%)$ \\
\hline $46-55$ & $19(18.3 \%)$ & $4(11.8 \%)$ \\
\hline $56-65$ & $5(4.8 \%)$ & $2(5.9 \%)$ \\
\hline Total & 104 & 34 \\
\hline \multicolumn{3}{|c|}{ Type of Virological Failure (RNA copies/ml) } \\
\hline Minimal Failure $\left(2,30<C V<3,70 \log _{10}\right)$ & \multicolumn{2}{|c|}{$8(23.5 \%)$} \\
\hline Moderate Failure $\left(3,70<C V<4,48 \log _{10}\right)$ & \multicolumn{2}{|c|}{$23(67.7 \%)$} \\
\hline Severe Failure $\left(C V>4,48 \log _{10}\right)$ & \multicolumn{2}{|c|}{$3(8.8 \%)$} \\
\hline
\end{tabular}

\subsection{Resistance and Treatment Failure}

In a previous study, the types of mutations and various associated prevalence were described for this population [15]. According to the Pearson's test, LVs at $6^{\text {th }}$ month were highly correlated with that of baseline $\left(\mathrm{R}^{2}=0.641, \mathrm{p}<0.000\right)$, with the K70 codon mutation for NRTI $\left(R^{2}=0.558, p<0.000\right)$, with the V75 for NRTI $\left(R^{2}=0.448, p<0.000\right)$, the V108 for NNRTI $\left(R^{2}=0.413, p<0.000\right)$ and with the virological treatment failure $\left(R^{2}=0.947, p<0.000\right)$. Some correlations in the onset of mutations in codons were denoted such as K70 NRTI and V75 NRTI $\left(\mathrm{R}^{2}=0.512, \mathrm{p}<0.000\right)$, K70 NRTI and T215 NRTI $\left(\mathrm{R}^{2}=0.453, \mathrm{p}<0.000\right)$, V75 NRTI and Y115 NRTI $\left(\mathrm{R}^{2}=0.465, \mathrm{p}<0.000\right)$, A98 NNRTI and V106 NNRTI $\left(\mathrm{R}^{2}=0.394, \mathrm{p}<0.000\right)$, V106 NNRTI and V108 NNRTI $\left(\mathrm{R}^{2}=0.595, \mathrm{p}<\right.$ $0.000)$, Y115 NRTI and A98 NNRTI $\left(R^{2}=0.359, \mathrm{p}<0.01\right)$, and Y115 NRTI and L100 NNRTI $\left(\mathrm{R}^{2}=0.593, \mathrm{p}<0.000\right)$.

\section{Discussion}

This study aimed to determine the rate of virological treatment failure and the involvement of genetic diversity and the different mutations in this failure in Kinshasa. It is the continuation of different studies published with the same population [15] [16] [17] [18].

After 6 months of ART, 10 cases (6.5\%) deaths and 5 cases (3.3\%) lost were recorded in the cohort of patients followed. For the case of death, the majority ( 8 patients) are women, while for the patients lost there are men $(3 \mathrm{men})$. Of the 138 patients (90.2\%) returned for their $6^{\text {th }}$ month follow-up, 81 (58.7\%) patients were women and 57 (41.3\%) men; thus giving a sex ratio $\mathrm{M} / \mathrm{F}$ of 0.70 . Different other studies have also published $\mathrm{M} / \mathrm{F}$ sex ratios that tend to feminize HIV infec- 
tion among adults in Kinshasa and in DRC [13]-[18] [22] [23].

According to the recommendations of the World Health Organization (WHO), 125 patients (90.5\%) were in clinical stage 3 and 13 (9.5\%) in clinical stage 4 after 6 months of treatment. While at baseline of the cohort, $91.5 \%$ of patients were in clinical stage 3 and $8.5 \%$ in clinical stage 4 [16]. This difference is not significant. Clinically, not many signs of improvement in the condition of different patients during different visits have been recorded.

Count CD4 $\mathrm{T}$ cells was made for 113 patients (71\%). The minimum and maximum values of CD4 $\mathrm{T}$ cells were 98 to 1050 cells $/ \mathrm{mm}^{3}$, respectively. The median CD4 cell count was 560 cells $/ \mathrm{mm}^{3}$ with 52 patients (46.02\%) with CD4 counts above 500 cells $/ \mathrm{mm}^{3}$. It was not possible to determine the immunological failure based on CD4 count due to the irregularity of this parameter in the patients. However, for all the patients who have the results at baseline and at the $6^{\text {th }}$ month, none were in immunological failure because the CD4 values have increased for all. The median increment of the differences in CD4 count at month 6 compared to baseline was of 247.5 cells $/ \mathrm{mm}^{3}$. This brings up the issue of the monitoring of People Living with HIV/AIDS (PLHIV) in our environment [23] [24].

The median VLs of the patients was $0.90 \log _{10}$ RNA copies/ml. The minimum and maximum values were respectively 0 and $4.82 \log _{10}$ RNA copies/ml with 104 patients (75.4\%) with a VL under $200 \mathrm{RNA}$ copies/ml or $2.3 \log _{10}$ RNA copies $/ \mathrm{ml}$ giving a failure rate of virological $24.6 \%$. Of the 34 patients in virological failure, $8(23.5 \%)$ are minimal failure $\left(2.30 \log _{10}<\mathrm{VL}<3.70 \log _{10}\right.$ RNA copies/ml), 23 $(67.7 \%)$ in moderate failure $\left(3.70 \log _{10}<\mathrm{VL}<4.48 \log _{10}\right.$ RNA copies/ml) and 3 $(8.8 \%)$ in severe failure (VL $>4.48 \log _{10}$ RNA copies/ml). Most failed patients $(67.7 \%)$ are moderate virological failure. In the past, virological failure was estimated at $14.6 \%$ in 2010 [25] and $16 \%$ in 2012 [13] for the city of Kinshasa, taking into account 3 clinics that were among the recommended centers for treatment at the time [24]. The difference in numbers is in the inclusion criteria of patients and selection centers, and the criteria for determining the processing failure. Indeed, the virological failure was redefined as a VL $>200$ RNA copies/ml (2.3 $\log _{10}$ RNA copies/ml) in 2013 [20] as opposed to a VL > 1000 copies of RNA copies/ml (3.0 $\log _{10}$ RNA copies/ml) in previous years [21]. In this study, 2 centers that met the criteria according to WHO's recommendations were randomly selected by district of Kinshasa [24]. Eight treatment centers participated in this study. Hence for Kinshasa, according to the updated criteria, the rate of virological failure is estimated at $24.6 \%$ for 2014 .

According to the Pearson's test, the VLs in the $6^{\text {th }}$ month were highly correlated with that of baseline $\left(\mathrm{R}^{2}=0.641, \mathrm{p}<0.000\right)$, with the K70 codon mutation for NRTI $\left(R^{2}=0.558, p<0.000\right)$, with the V75 for NRTI $\left(R^{2}=0.448, p<0.000\right)$, with the V108 for NNRTI $\left(R^{2}=0.413, p<0.000\right)$, and with the virological treatment failure $\left(\mathrm{R}^{2}=0.947 ; \mathrm{p}<0.000\right)$. Various studies have shown that a high VL $\left(\mathrm{CV}>5.00 \log _{10}\right)$ before starting treatment is a badprognosis for treatment, where the patient is doomed to failure [26] [27]. Some studies have implicated 
the $\mathrm{K} 103 \mathrm{~N}$ and $\mathrm{Y} 181 \mathrm{C}$ mutations for resistance and failure to treatment [28] [29]. But in our case, the mutated codons that are responsible for treatment failure are: K70, V75 for NRTI and V108 for NNRTI. This presents a profile of different resistance mutations to Kinshasa specific to the different variants; this corresponds to what has been published in Africa for non-B subtypes [30].

On the other hand, some correlations in the emergence of codons mutations were noted such as K70 NRTI and V75 NRTI $\left(R^{2}=0.512, p<0.000\right)$, K70 NRTI and T215 NRTI $\left(\mathrm{R}^{2}=0.453, \mathrm{p}<0.000\right)$, V75 NRTI and Y115 NRTI $\left(\mathrm{R}^{2}=0.465, \mathrm{p}\right.$ $<0.000)$, V106 NNRTI and V108 NNRTI $\left(\mathrm{R}^{2}=0.595, \mathrm{p}<0.000\right)$ as well as Y115 NRTI and L100 NNRTI $\left(\mathrm{R}^{2}=0.593 ; \mathrm{p}<0.000\right)$.

\section{Limitation of Study}

Due to different constraints, the determination of mutations $6^{\text {th }}$ month after the beginning of treatment was not done. However, this does not remove the pertinence of the results. They related to the involvement of transmitted mutations in the treatment failure and responded to the prerogatives and actual questions on mutations.

\section{Conclusion}

Our results confirmed the hypothesis that high Viral Load at start of treatment is a poor prognosis for the therapeutic development of the patient. Correlations between virological failure, acquired mutations and viral load at baseline reinforce the importance of the usefulness of genotyping tests and viral load in early treatment to improve treatment and for adequate therapy.

\section{Conflict of Interest}

The authors declare that they have no conflict of interest.

\section{Authors' Contribution}

EK and DV conceived the study. MPH, RK and GM participated in the study design. EK coordinated data collection. EK performed laboratory work, data analysis and interpretation of results. DV coordinated laboratory analysis and participated in interpretation of results. EK drafted the manuscript. All authors contributed to the writing, read and approved the final manuscript.

\section{References}

[1] Kamangu, N.E., Kabututu, Z.P., Mvumbi, L.G., Kalala, L.R. and Mesia, K.G. (2013) Genetic Diversity of Human Immunodeficiency Virus Type 1 in the Democratic Republic of Congo: A Review of Available Data. International Journal of Collaborative Research on Internal Medicine and Public Health, 5, 295-309.

[2] Kandathil, A.J., Ramalingam, S., Kannagai, R., David, S. and Sridharan, G. (2005) Molecular Epidemiology of HIV. Indian Journal of Medical Research, 121, 333-344.

[3] Takebe, Y., Kusagawa, S. and Motomura, K. (2004) Molecular Epidemiology of HIV: Tracking AIDS Pandemic. Pediatrics International, 46, 236-244. https://doi.org/10.1046/j.1442-200x.2004.01869.x 
[4] Thomson, M.M. and Nájera, R. (2005) Molecular Epidemiology of HIV-1 Variants in the Global AIDS Pandemic: An Update. AIDS Reviews, 7, 210-224.

[5] Etienne, L. and Peeters, M. (2010) Origine du VIH, une réussite émergentielle. Virologie, 14, 171-183.

[6] Hemelaar, J., Gouws, E., Ghys, P.D. and Osmanov, S. (2006) Global and Regional Distribution of HIV-1 Genetic Subtypes and Recombinants in 2004. AIDS, 20, W13-W23. https://doi.org/10.1097/01.aids.0000247564.73009.bc

[7] Shao, Y. and Williamson, C. (2012) The HIV-1 Epidemic: Low- to Middle-Income Countries. Cold Spring Harbor Perspectives in Medicine, 2, a007187. https://doi.org/10.1101/cshperspect.a007187

[8] Coffin, J.M. (1995) HIV Population Dynamics in Vivo: Implications for Genetic Variation, Pathogenesis, and Therapy. Science, 267, 483-489. https://doi.org/10.1126/science.7824947

[9] Eshleman, S.H., Becker-Pergola, G., Deseyve, M., Guay, L.M., Mracna, M., Fleming, T., Cunningham, S., Musoke, P., Mmiro, F. and Jackson, J.B. (2001) Impact of Human Immunodeficiency Virus Type 1 (HIV-1) Subtype on Women Receiving Single-Dose Nevirapine Prophylaxis to Prevent HIV-1 Vertical Transmission (HIV Network for Prevention Trials 012 Study). The Journal of Infectious Diseases, 184, 914-917. https://doi.org/10.1086/323153

[10] Brenner, B., Turner, D., Oliveira, M., Moisi, D., Detorio, M., Carobene, M., Marlink, R.G., Schapiro, J., Roger, M. and Wainberg, M.A. (2003) A V106M Mutation in HIV-1 Clade C Viruses Exposed to Efavirenz Confers Cross-Resistance to Non-Nucleoside Reverse Transcriptase Inhibitors. AIDS, 17, F1-F5. https://doi.org/10.1097/00002030-200301030-00001

[11] Loemba, H., Brenner, B., Parniak, M.A., Ma'ayan, S., Spira, B., Moisi, D., Oliveira, M., Detorio, M. and Wainberg, M.M.A. (2002) Genetic Divergence of Human Immunodeficiency Virus Type 1 Ethiopian Clade C Reverse Transcriptase (RT) and Rapid Development of Resistance against Nonnucleoside Inhibitors of RT. Antimicrobial Agents and Chemotherapy, 46, 2087-2094. https://doi.org/10.1128/AAC.46.7.2087-2094.2002

[12] Delfraissy, J.F. (2005) Prise en charge thérapeutique des personnes infectées par le VIH. Rapport 2004, Médecine-Sciences, Flammarion.

[13] Kamangu, N.E., Kawila, M.E., Mukumbi, H. and Mvumbi, L.G. (2012) Estimated Rates of Treatment Failure in First-Line Antiretroviral Treatment in Kinshasa: Case of the ACS AMO-Congo. International Journal of Collaborative Research on Internal Medicine and Public Health, 4, 885-891.

[14] Programme National de Lutte contre le VIH/SIDA et les Infections Sexuellement Transmissible (PNLS), Ministère de la Santé Publique, République Démocratique du Congo (RDC) (2013) Guide National de Prise en Charge de l'Infection à VIH en RDC. Version révisé.

[15] Kamangu, N.E., Chatte, A., Susin, F., Boreux, R., Kalala, L.R., Mvumbi, L.G., De Mol, P., Vaira, D. and Hayette, M.P. (2015) Genetic Diversity and Antiretroviral Drug Resistance among Drug-Naïve HIV Type 1 Infected Patients Attending Clinics in Kinshasa, Democratic Republic of Congo. Journal of HIV and AIDS, 1.

[16] Kamangu, N.E., Bulanda, I.B., Bongenia, I.B., Botomwito, T.H., Mvumbi, L.G., De Mol, P., Vaira, D., Hayette, M.P. and Kalala, L.R. (2015) Virological Profile of Patients Infected with HIV Starting Antiretroviral Treatment in Kinshasa. Open Access Library Journal, 2, e1564. https://doi.org/10.4236/oalib.1101564

[17] Kamangu, N.E., Chatte, A., Boreux, R., Kalala, L.R., Mvumbi, L.G., De Mol, P., Vaira, D. and Hayette, M.P. (2014) Implementation of an In-House Quantitative 
Real-Time PCR for Determination of HIV Viral Load in Kinshasa. Open Access Library Journal, 1, e855. https://doi.org/10.4236/oalib.1100855

[18] Kamangu, N., Chatte, A., Boreux, R., Kalala, L.R., Mvumbi, L.G., Vaira, D. and Hayette, M.P. (2014) Mise en place d'une PCR Quantitative Temps Réel pour la détermination de la Charge Virale VIH à Kinshasa. Journal des Recherches BioMédicales, 1, 7-12.

[19] Kamangu, N.E., Chatte, A., Boreux, R., Susin, F., Kalala, L.R., Mvumbi, L.G., De Mol, P., Hayette, M.P. and Vaira, D. (2015) Comparison of an In-House Quantitative Real Time PCR and COBAS AmpliPrep/TaqMan Roche for Determination of Viral Load for HIV Type 1 Non-B. Open Access Library Journal, 2, e1402. https://doi.org/10.4236/oalib.1101402

[20] Morlat, P. (sous la direction de) (2014) Prise en Charge Médicale des Personnes Vivant avec le VIH: Recommandations du Groupe d'experts. Sous l'égide du CNS et de l'ANRS. Rapports 2013.

[21] Yéni, P. (sous la direction de) (2010) Prise en charge médicale des personnes infectées par le VIH. Recommandations du groupe d'Experts. Médecine Sciences, Flammarion, Paris.

[22] Kamangu, N.E., Situakibanza, N.H., Mvumbi, L.G., Kakudji, I.L., Tshienda, T.D. and Mesia, K.G. (2012) Infections Opportunistes chez les Personnes Vivant avec le VIH suivi à l'Hôpital Militaire de Référence de Kinshasa (Camp Kokolo). Revue Congolaise des Sciences, 1, 66-76.

[23] Bongenya, B., Ilombo, L., Botomwito, H., Bulanda, B., Kamangu, E., Lusakibanza, M. and Mesia, G. (2014) Fréquence du Suivi des Paramètres Biologiques des Patients sous Antirétroviraux à Kinshasa: Cas de l'Hôpital Provincial Général de Référence. Journal des Recherches BioMédicales, 1, 1-6.

[24] Kamangu, N.E., Kalala, N.H. and Mesia, K.G. (2012) Profile of Antiretroviral Treatment Centers in Kinshasa, Democratic Republic of Congo [Poster 388]. Proceedings of the 1 st International African Society of Laboratory Medicine (ASLM) Conference, Cape Town, 1-7 December 2012, 377.

[25] Muwonga, J., Edidi, S., Butel, C., Vidal, N., Monleau, M., Okenge, A., Mandjo, J.L., Mukumbi, H., Muyembe, J.J., Mbayo, F., Kayembe, D., Delaporte, E., Boillot, F. and Peeters, M. (2011) Resistance to Antiretroviral Drugs in Treated and Drug-Naïve Patients in the Democratic Republic of Congo. Journal of Acquired Immune Deficient Syndrome, 57, S27-S33. https://doi.org/10.1097/QAI.0b013e31821f596c

[26] Egger, M., May, M. and Chêne, G. (2002) Prognosis of HIV-1-Infected Patients Starting Highly Active Therapy: A Collaborative Analysis of Prospective Studies. The Lancet, 360, 119-129. https://doi.org/10.1016/S0140-6736(02)09411-4

[27] Phair, J.P., Mellors, J.W., Detels, R., Margolick, J.B. and Munoz, A. (2002) Virologic and Immunologic Values Allowing Safe Deferral of Antiretroviral Therapy. AIDS, 16, 2455-2459. https://doi.org/10.1097/00002030-200212060-00011

[28] Anejo-Okopi, J.A., Agbaji, O.O., Agaba, P.A., Ugoagwu, P.O., Were, K., Onywera, H., Owiti, P., Isa, S.E., Otecko, N., Okwori, A.E.J., Musa, J., Oguche, S., Sagay, A.S., Idoko, J.A., Nimzing, L., Jatau, E.D. and Olonitola, O.S. (2013) Human Immunodeficiency Virus Type 1 (HIV-1) Genetic Diversity and Prevalence of Antiretroviral Drug Resistance Mutations in Treatment-Naïve Adults in Jos, North Central Nigeria. African Journal of Biotechnology, 12, 2279-2287. https://doi.org/10.5897/AJB2013.11954

[29] Afonso, J.M., Bello, G., Guimaraes, M.L., Sojka, M. and Morgado, M.G. (2012) HIV-1 Genetic Diversity and Treatment Drug Resistance Mutations among Patients from North, Central and South Regions of Angola. PLOS ONE, 7, e42996. 
https://doi.org/10.1371/journal.pone.0042996

[30] Santos, A.F. and Soares, M.A. (2010) HIV Genetic Diversity and Drug Resistance. Virus, 2, 503-531. https://doi.org/10.3390/v2020503

\section{Abbreviations}

3TC: Lamivudine; ABC: Abacavir; AIDS: Acquired Immuno Deficiency Syndrome; ART: Antiretroviral Treatment; ARV: Antiretroviral; CD4: Cluster for Differentiation T4; CHU-ULg: Centre Hospitalier Universitaire, Université de Liège; CRF: Circulating Recombinant Forms; d4T: Stavudine; ddI: Didanosine; EFV: Efavirenz; HIV: Human Immunodeficiency Virus; LPV/r: Lopinavir boosted with Ritonavir; NNRTI: Non Nucleotide Reverse Transcriptase Inhibitor; NVP: Nevirapine; NRTI: Nucleotide Reverse Transcriptase Inhibitor; PCR: Polymerase Chain Reaction; PI: Protease Inhibitor; RNA: RiboNucleic Acid; RT: Reverse Transcriptase; UNIKIN: University of Kinshasa; VL: Viral Load; ZDV: Zidovudine.

\section{Scientific Research Publishing}

Submit or recommend next manuscript to SCIRP and we will provide best service for you:

Accepting pre-submission inquiries through Email, Facebook, LinkedIn, Twitter, etc. A wide selection of journals (inclusive of 9 subjects, more than 200 journals)

Providing 24-hour high-quality service

User-friendly online submission system

Fair and swift peer-review system

Efficient typesetting and proofreading procedure

Display of the result of downloads and visits, as well as the number of cited articles

Maximum dissemination of your research work

Submit your manuscript at: http://papersubmission.scirp.org/

Or contactwja@scirp.org 